This item was submitted to Loughborough's Research Repository by the author.

Items in Figshare are protected by copyright, with all rights reserved, unless otherwise indicated.

\title{
Empowering the project team: impact of leadership style and team context
}

PLEASE CITE THE PUBLISHED VERSION

http://dx.doi.org/10.1108/13527591211241006

PUBLISHER

(c) Emerald

VERSION

AM (Accepted Manuscript)

LICENCE

CC BY-NC-ND 4.0

REPOSITORY RECORD

Tuuli, Martin Morgan, Steve Rowlinson, Richard Fellows, and Anita Liu. 2019. "Empowering the Project Team: Impact of Leadership Style and Team Context”. figshare. https://hdl.handle.net/2134/11504. 
This item was submitted to Loughborough's Institutional Repository (https://dspace.lboro.ac.uk/) by the author and is made available under the following Creative Commons Licence conditions.

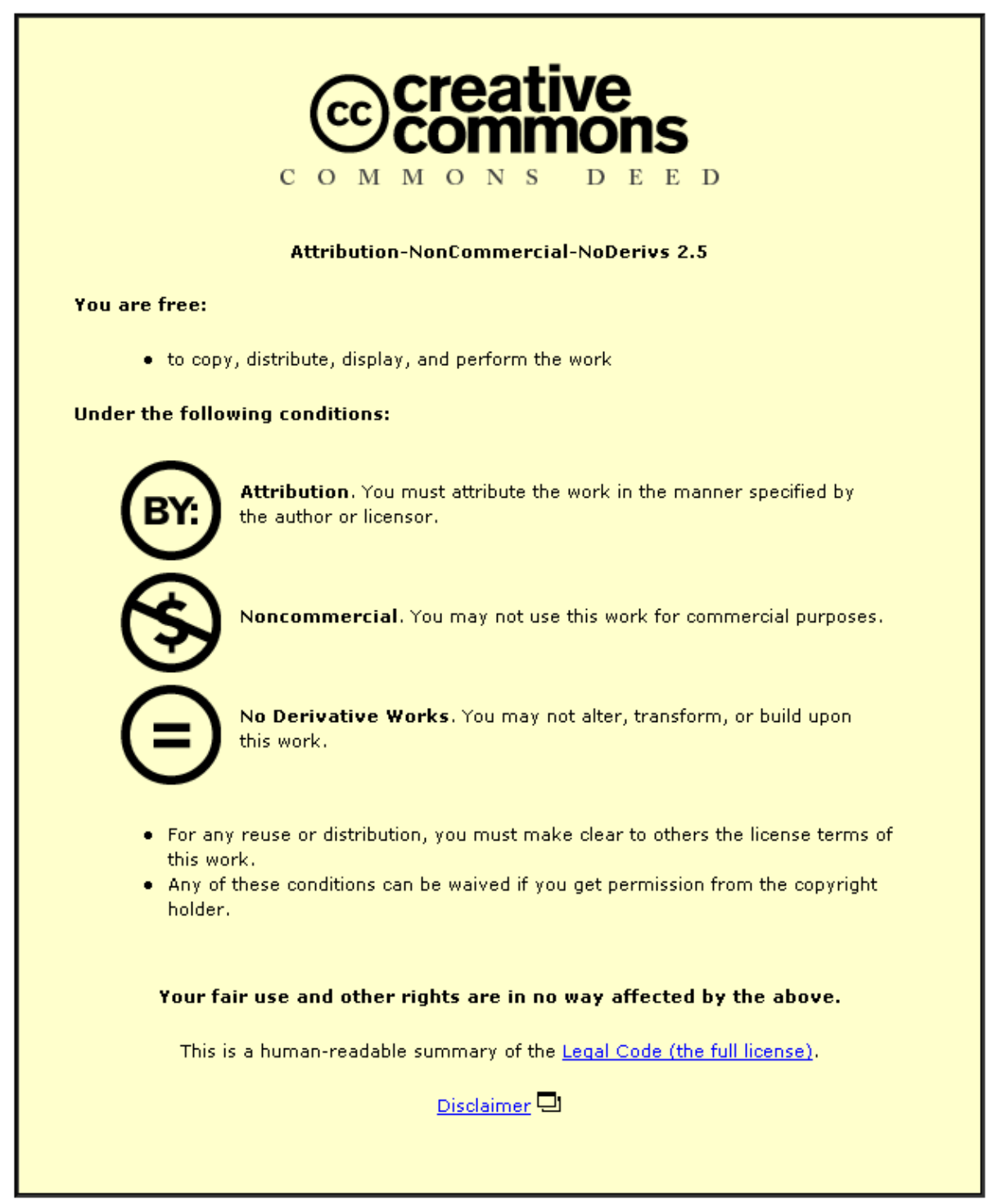

For the full text of this licence, please go to: http://creativecommons.org/licenses/by-nc-nd/2.5/ 


\title{
EMPOWERING THE PROJECT TEAM: IMPACT OF LEADERSHIP STYLE AND TEAM CONTEXT
}

\begin{abstract}
Purpose: The empowerment process makes huge demands on organizations and their constituents. Identifying the individual-, interpersonal- and organizational-level factors that impact empowerment perceptions therefore bridges an important knowledge gap. This paper examines the impact of leadership style and team context on structural and psychological empowerment perceptions in project teams.
\end{abstract}

Design/methodology/approach: It was posited that span of control and within team interdependence will positively and significantly influence both structural and psychological empowerment. Person orientated leadership style was also expected to positively impact both structural and psychological empowerment while task orientated leadership style was expected to have a negative impact. These hypothesized relationships were examined using Ordinary Least Square (OLS) Regression and Hierarchical Linear Modelling (HLM) with data obtained through a parallel quantitative questionnaire survey of construction client, consultant and contractor organizations in Hong Kong.

Findings: No significant relationship was found between span of control and any facet of empowerment while team interdependence had a positive and significant relationship with psychological empowerment but not structural empowerment. Task orientated leadership was positively and significantly related to psychological empowerment in the full sample and contractor teams but not in consultant and client teams. Person orientated leadership was positively and significantly related to psychological empowerment in the full sample, consultant and client teams but not in contractor teams.

Research Implications/Limitations: The distinct findings in relation to the leadership styleempowerment link are consistent with a systems perspective of the construction process. Client and consultant teams constitute a "managing sub-system" and rely on management of interrelationships (i.e. person orientated leadership) to succeed while contractor teams constitute the "operating/task sub-system" and rely on task performance (i.e. task orientated leadership). In project settings where "getting the job done" and "teamwork" are inseparable, both leadership styles can produce positive outcomes through "leadership adjustment". A limitation of the study is its focus only the behavioural perspective of leadership as compared to more recent perspectives on leadership.

Originality/value: The link between leadership style, team context and three facets of empowerment are examined compared with previous studies often focusing on one facet. Subsample analysis enabled more subtle differences of the impact of leadership style in different context to be revealed, an indication that samples may not be homogeneous.

Keywords: person orientated leadership, empowerment, span of control, task orientated leadership, team interdependence, Hong Kong. 


\section{INTRODUCTION}

What empowers individuals and teams, especially in project contexts, have become important areas of enquiry following increasing evidence that what holds in permanent organizational settings does not necessarily generalize to temporary organizational settings such as projects (Bryman et al., 1987, Kirkman et al, 2004, Tuuli, 2009, Nauman, Mansur Khan \& Ahsan, 2010). There is also a widespread difficulty, and misplaced perception, that theories and many empirical findings of Western research and from Western subjects apply universally. Given research into national cultures and cross cultural studies (e.g., Hofstede, 2001), there is a well-established and growing body of evidence that cultures, and what depends upon them - including values, behaviour and perceptions - vary significantly; within national culture variation may also be significant. Thus, despite widespread assertions that empowerment is 'good' and so, is desired, that assertion should be tempered through attention to the cultures of the persons to whom it is being applied.

Mwaura, Sutton, and Roberts (1998) from studying staff at a major hotel in Beijing, for example, found that both Chinese managers and operatives did not want to accept responsibility, even if they had appropriate authority, but preferred to pass the responsibility to expatriate managers. That finding raises questions over the effectiveness of empowerment in culturally-ordered hierarchies, especially where persons from individualistic cultures head the structure. There are therefore implications for both the design of management structures for effectiveness and efficiency, and the potential role conflict through persons failing to exercise appropriate positional power (French and Raven, 1959).

These issues however reinforce the need to study the underlying influences of empowerment from different levels, cultures and contexts. Yet, while researchers and management practitioners alike acknowledge that perception of empowerment is affected by a variety of 
individual-, interpersonal- and organizational-level factors, no concerted efforts have been made to integrate those diverse perspectives and so, bridge this knowledge gap. A recent qualitative study by Tuuli and Rowlinson (2010) identified a range of factors from the individual, team, organization and project contexts that impact empowerment perceptions in project settings in Hong Kong. However, it remains unknown to what extent these findings generalize across construction and project organizations. To promote understanding and conceptual development of the empowerment concept and how it manifests itself, identifying the underlying factors that engender empowerment perceptions in project settings is an important first step.

The focus here is on empowerment as both a psychological experience of individuals and teams, and as a structural concept (empowerment climate). The study explores how leadership style, team interdependence and span of control, representing interpersonal and team-context specific factors, influence empowerment in construction project teams. First, we examine the empowerment concept from the psychological and structural perspectives, and from a multilevel perspective arguing that empowerment is an isomorphic concept that can be examined at the individual- and team-levels. Second, leadership is examined from a behavioural perspective noting that other researchers have recently examined other perspectives of leadership such as leadership development, transformational leadership, a competency perspective, emotional leadership and authentic leadership. Third, we discuss team context, noting the importance of two team context specific factors, span of control and interdependence, which encapsulate the social interactions in teams. Building on this foundation, we outline several hypotheses linking leadership styles, team context factors and the three facets of empowerment (i.e. empowerment climate, individual and team psychological empowerment. Using data from a parallel questionnaire survey of project management teams of client, consultant and contractor organizations in Hong Kong, these 
hypotheses are tested using Ordinary Least Square (OLS) Regression and Hierarchical Linear Modelling (HLM). The tests reveal both expected and unexpected findings. In particular, distinct findings emerged in relation to the leadership-empowerment link in different teams, consistent with a systems perspective of the construction process and the notion of leadership adjustment in project teams.

\section{EMPOWERMENT, LEADERSHIP AND TEAM CONTEXT}

\subsection{Empowerment}

Within the extant literature, empowerment is distinctively conceptualised as a structural concept and as a psychological concept. As a structural concept, empowerment is deeply rooted in job design and occurs through objective and, often, formal organizational changes that grant individuals greater latitude to make decisions and exert influence regarding their

work (Liden and Arad, 1996). . From this perspective, previous researchers (e.g. Kanter, 1977, Conger and Kanungo, 1988, Bowen and Lawler, 1992, Eylon and Bamberger, 2000) have identified various structural dimensions in organizations as empowering. For example, Seibert et al (2004) conceptualized structural empowerment as empowerment climate, representing the shared perceptions among organizational constituents of the organizational conditions that foster feelings of empowerment. Building on the work of Blanchard and his colleagues (Blanchard et al., 1999), Seibert et al (2004) depict empowerment climate as multi-dimensional comprising three organizational practices; information sharing, autonomy through boundaries, and team accountability. This mirrors the early work of Kanter (1977, 1993) in which she identified six structural dimensions of the work environment as empowering; access to information, support, access to resources, opportunity to learn and grow, access to formal power sources, and access to informal power sources. 
Mills and Ungson (2003), however, argue that the structural perspective of empowerment represents a "moral hazard dilemma" for managers, as its success or failure depends on the ability of managers to reconcile the potential inherent loss of control with the fundamental organizational need for goal congruence. This perspective of empowerment is also criticised for its failure to address the cognitive state of those being empowered. Thus, in some situations, power, knowledge, information and resources are shared, yet employees still evince disempowerment and, in other situations, all the objective features of an empowering work climate are absent, yet employees feel and act empowered (Spreitzer and Doneson, 2008). These concerns cumulated in the development of the psychological perspective of empowerment.

The psychological perspective proposes that empowerment is a constellation of experienced cognitions. According to Spreitzer and Quinn (2001: 13-14) psychologically empowered individuals and teams "see themselves as having freedom and discretion (self-determination), as having a personal connection to the organization (meaning), as confident about their abilities (competence), and as able to make a difference in the system in which they are embedded (impact)". Taking the perspective of the state of mind of the individual, Menon (2001: 161) defined the psychologically empowered state as "a cognitive state characterized by a sense of perceived control, competence and goal internalization”.

Psychological empowerment has also been portrayed as an isomorphic construct (c.f. Kirkman and Rosen, 1997, Kirkman and Rosen, 1999, Spreitzer, 1996) and thus, retains the same basic meaning, structure and function across levels of analysis (Klein and Kozlowski, 2000, Chen et al., 2007). This multilevel view implies that psychological empowerment can manifest as an individual experience and as a shared team or work-group experience (c.f. Kirkman and Rosen, 1997, Kirkman and Rosen, 1999, Mathieu et al., 2006). Team psychological empowerment reflects "team members' collective belief that they have the 
authority to control their proximal work environment and are responsible for the team's functioning" (Mathieu et al., 2006: 98). Psychological empowerment is, however, often criticised for being individually-centric (Spreitzer, 2008) and, thus, focussing too much attention on 'overworked symbolic gestures' while ignoring the underlying substantive changes that take place within the work environment (Hardy and Leiba-O'Sullivan, 1998). Also problematic is the implicit assumption of psychological empowerment that as long as employees can be made to believe they are empowered, it does not matter whether they actually are or not. The findings of Greasley et al. (2005) are evident of the discordance that can arise between management rhetoric and employee experience of empowerment, and reaffirms that empowerment interventions cannot be just 'window dressing'. Forrester (2000, p. 69) also points out that "the notion of psychological empowerment provides less leverage to organizations in a practical sense because [organizations] have only limited capacity to influence employee's inner workings".

Although the structural and psychological perspectives of empowerment are conceptually distinct and provide different lenses for understanding empowerment in the work place (Spreitzer and Doneson, 2008), their complementarities are apparent from both theoretical and empirical perspectives (c.f. Tuuli and Rowlinson, 2007a, Tuuli and Rowlinson, 2007b). Thus, rather than being pursued separately, integrating them provides a unifying explanation of the dynamics of the empowerment process (Menon, 2001, Mathieu et al., 2006). Within construction context, capacity to develop effective empowerment strategies for organizations is hindered by inadequate understanding of industry specific dynamics of empowerment. Thus, although the antecedents of empowerment have been examined in other industrial settings (e.g. Spreitzer, 1995b, Koberg et al., 1999, Kirkman and Rosen, 1999, Menon and Pethe, 2002, Mathieu et al., 2006), the special operating environment of the construction industry makes the study of contextual antecedents in project settings a justifiable agenda. 
Particularly, the findings of these previous studies cannot be generalized adequately to explain the levels of empowerment that will be expected in construction project context for two main reasons. First, these studies have generally focussed on 'permanent teams' and employees in often single permanent organizational settings. Permanent organizations are generally more 'hierarchical' and 'mechanistic' in nature compared with the more 'organic' nature of temporary organizational systems such as construction projects (Bryman et al., 1987). Second, temporary organizational systems are also characterized by higher stress levels, due to high uncertainty, tight deadlines and higher levels of role ambiguity (Yip, Rowlinson and Siu, 2008, Yip and Rowlinson, 2009). Thus, it is reasonable to assume that the dynamic interplay of the contextual factors will differ in permanent and temporary organizational settings.

\subsection{Leadership}

Hersey and Blanchard (1982) define leadership style in terms of the perceived consistent pattern of behaviours that leaders use when they work with and through people. According to Tannenbaum and Schmidt (1973) leadership style is influenced by four factors; the leader's value system, confidence in subordinates, leadership inclinations and feelings of security in uncertain situations. Based on this premise, they depict leadership style as existing on a continuum; from a democratic or subordinate centred style to an authoritarian or leader centred style. This depiction parallels the conceptualization of leadership style as either

employee orientated (person) or production orientated (task) by the Michigan Leadership Studies (c.f. Katz et al., 1987), and the consideration and initiating structure dichotomy 
proposed by the Ohio State Leadership Studies (c.f. Stodill and Coons, 1957). This dichotomy of leadership styles from a behavioural perspective is pervasive in the development of many of the popular and contemporary schools of thought on leadership (c.f. Fleishman et al., 1991; Strang, 2005, Muller and Turner, 2007). For instance, Blake and Mouton's (1964) Managerial Grid, Hersey and Blanchard's (1982) situational leadership theory, and Bass' (1985) transformational and transactional leadership behaviours. Thus, although other researchers have recently examined leadership from different perspectives such as leadership development (e.g. Skipper and Bell, 2006a,b, Skipper and Bell, 2008, Toor and Ofori, 2008a), transformational leadership (e.g. Keegan and Den Hartog, 2004), emotional aspects of leadership (e.g. Goleman, Boyatzis, and McKee, 2002, Butler and Chinowsky, 2006), competency perspectives (e.g. Dulewicz, and Higgs, 2003, Muller and Turner, 2007, Debrah and Ofori, 2005) and authentic leadership (e.g. Toor and Ofori, 2008b) we focus on the behavioural perspective, the dominant perspective on leadership studies in projects (Toor and Ofori, 2008c), and examine in particular the impact of task and person orientated leadership styles on empowerment perceptions. This focus is also supported by a recent meta-analytic review of the antecedents of empowerment by Seibert, Wang and Courtright (2011) which showed that positive forms of leadership, of which the behavioural perspective is part, increase employees' perception of empowerment.

\subsection{Team Context}

The team or work-unit is the proximal social environment of individuals and creates opportunities for interactions that, subsequently, shape behaviours, attitudes and perceptions. A key feature of teams is a clear boundary which determines membership and the scope of interactions. An example of a boundary issue in teams is span of control, often 
operationalized as the number of members or team size. Span of control reflects the level of direct control a leader has over individual team members and is, therefore, often used as an indicator of the authority, responsibility or control possessed by a manager. It is also a measure of the closeness of contact between a leader and subordinates (Ouchi and Dowling, 1974), a view that reflects what Antonakis and Atwater (2002) refer to as structural distance, the physical distance between leader and follower or the frequency of leader-follower interaction. Usefully, span of control may be viewed in the context of power distance, and analysed relative to norms in the societal context, rather than on some absolute scale. That is of particular import for intercultural contexts.

Other key features of teams are common (accepted) goals and interdependence of members. Indeed, it is common goals and the level of interdependence that differentiates a team from a group. Interdependence in team settings reflects the extent to which team members need to mutually interact, communicate and coordinate to accomplish tasks (Saavedra et al., 1993). Steiner (1972) characterized interdependence as process interaction while Thompson (1967) conceptualized it in terms of work-flow processes and proposed three basic work-flow arrangements or task interdependence reflecting an increasing level of dependence and need for coordination; pooled, sequential and reciprocal interdependence. Van de Ven et al. (1976) added a fourth arrangement; team interdependence, as an extension to Thompson's (1967) work, which represents the highest in the order of increasing dependence and need for coordination. Team interdependence comprises two dimensions - within-team and betweenteam interdependence; the positioning of team activities / behaviour on those two dimensions impact on coordination requirements (as well as other aspects of boundary spanning).

To the extent that span of control and interdependence shape behaviours, attitudes and perceptions at the team-level, these team contextual factors have implications for the empowerment perceptions of individuals and teams. 


\section{DEVELOPMENT OF HYPOTHESES}

\subsection{Leadership style and empowerment}

Leaders provide vision and direction for the pursuance of group and organizational goals. Indeed, Chen and Kanfer (2006: 252) assert that "in work settings, leadership arguably represents the most important of all contextual factors, which might affect individual and team motivation". Leadership, particularly, provides a direct channel through which individuals interpret organizational policies and practices. Leader behaviour, manifested in the style of leadership, thus, play a key role in shaping employee interactions, behaviour and perceptions.

The empowering nature of leadership is further supported by social exchange theory (Keller and Dansereau, 1995). The social exchange that occurs among individuals and between individuals and their leaders therefore plays a key role in shaping individual construction of meaning in organizations. Leader-member exchange from exchange theory suggests that leaders differentiate in their treatment of subordinates, creating a dichotomy of in-group and out-group members among subordinates (Dansereau et al., 1975, Dienesch and Liden, 1986). Leaders then establish high-quality relationships with in-group members and low-quality relationships with out-group members (Liden et al., 2000). The support and responsibility that leaders grant subordinates therefore depends on whether subordinates are in-group or out-group members. Viewed in that light, the treatment of in-groups may be likened to person orientated leadership while out-group treatment is consistent with task orientated leadership behaviours. This view is supported by Keller and Dansereau (1995) who contend that supervisors for example employ leadership techniques, characterized by the provision of support and challenging tasks, in their dealings with in-groups and directive and close 
supervision with out-groups. The empowering nature of leadership will therefore depend on the leader's position on the orientation continuum, ranging from completely person orientated leadership at one end to completely task orientated leadership at the other end.

Essentially, the person orientated end of the continuum reflects a non-directive, relationship based leadership that emphasizes trust and mutual respect between leaders and subordinates. At the other end of the continuum, the task orientated aspect places emphasis on the task or the technical aspects of the work. Person/relationship based leadership style should, therefore, play an important role in structural and psychological empowerment through the creation of an enabling environment for subordinates to exercise personal control while task based leadership style will militate against personal control, and hence, empowerment, as result of its task-centric perspective. Transformational leadership behaviours and relationship/person orientated leadership behaviours which are consistent with positive leadership (Seiber, Wang \& Courtright, 2011), exhibit the most direct link to empowerment. Indeed, providing employees with a sense of vision, mission, support and opportunity for development are among the most empowering behaviours that can emanate from a leader (Lawler, 1992). In support, Spreitzer (2008) concluded from a narrative review that a supportive, trusting relationship with one's leader is an important contextual antecedent of psychological empowerment.

Consistent with the social exchange theory that aligns person orientated leadership style (positive leadership behaviours) with empowerment, as well as prior research findings linking transformational leadership and other positive forms of leadership to empowerment (Jung and Sosik, 2002, Seibert, Wang \& Courtright, 2011), we posit that;

H1: Leadership style within the team will influence empowerment such that: (a) task orientated leadership style is negatively and significantly related to individual psychological 
empowerment, and (b) person orientated leadership style is positively and significantly related to individual psychological empowerment;

H2: Leadership style within the team will influence empowerment such that: (a) task orientated leadership style is negatively and significantly related to team psychological empowerment, and (b) person orientated leadership style is positively and significantly related to team psychological empowerment; and

H3: Leadership style within the team will influence empowerment such that: (a) task orientated leadership style is negatively and significantly related to empowerment climate, and (b) person orientated leadership style is positively and significantly related to empowerment climate.

\subsection{Team-context and empowerment}

The link between social interactions and empowerment has a long history, dating to the work of Lewin (1947) in employee involvement and the sociotechnical systems research on autonomous workgroups (c.f. Trist and Bamforth, 1951). Span of control and interdependence constitute team-context specific features with implications for control and hence, empowerment in teams. For example,

Tesluk et al. (1997) contend that the implementation of team-based interventions should be guided by the team's task interdependence. The implication of interdependence for empowerment is particularly profound from the perspective of the level of task interdependence. Low interdependence, typical in pooled or sequential tasks, may induce higher individual empowerment, since the discrete tasks they comprise are performed independently (in parallel or/and sequence - but, for project completion, must come together 
eventually and so, exhibit low temporal dependence). However, in high task interdependence situations, such as in reciprocal or intensive tasks (high temporal dependence), team members may be empowered both individually and collectively in order to maximise the interactions for task accomplishment (Tuuli and Rowlinson, 2007).

Interdependence within cross-functional teams, such as construction, is perpetuated by specialisation or the distinct expertise of the team members and should, therefore, lead to greater empowerment since effective task performance in teams typically requires individuals to work in concert with others (team effort); yet, task-specific knowledge (professionalism) requires independent input (individual effort). Therefore, the group performs effectively when all members are empowered to perform their individual inputs and those inputs are coordinated well.

From the foregoing, we posit that team context influences empowerment such that withinteam interdependence is positively and significantly related to (H1c) individual psychological empowerment; (H2c) team psychological empowerment, and (H3c) empowerment climate.

Narrow spans of control or structural distance are associated with closer superior-subordinate contact and, hence, closer supervision and direct reporting. Individuals working in wide spans of control should, thus, experience less direct control by their leaders and, therefore, experience greater flexibility in the accomplishment of tasks. Quinn and Spreitzer (1997) assert that it is very difficult for managers to micro-manage in large span of control conditions. Thus, "even if a boss does not want to delegate decision-making, the greater number of subordinates that report to him or her, the more difficult it becomes to make all decisions for each subordinate" (Spreitzer, 1996, p. 497-498). To restrict empowerment distribution in large span of control situations may require more levels in the management 
hierarchy. Large span of control should, therefore, create a more empowering work climate that, in turn, engenders psychological empowerment.

Thus, team context influences empowerment such that large span of control is positively and significantly related to: (H1d) individual psychological empowerment; (H2d) team psychological empowerment, and (H3d) empowerment climate.

\section{RESEARCH METHOD}

\subsection{Sample}

The sample comprises individuals in "project management teams" in the Hong Kong construction industry. Construction project organizations (i.e. contractor, consultant and client related) where first sampled and the individuals and teams surveyed through identified key contact persons. As there is no known population of the target organizations in Hong Kong, various data bases were relied upon to build a comprehensive sample frame of organizations for the study. Specifically, the Hong Kong Special Administrative Region (HKSAR) of China Government lists of approved contractors and consultants for public works were the starting point. These lists were supplemented with the lists from various professional organizations, notably The Hong Kong Construction Association, Association of Consulting Engineers of Hong Kong, Association of Consulting Quantity Surveyors, Construction Industry Institute (Hong Kong), Hong Kong Institute of Architects, Hong Kong Institute of Engineers, Hong Kong Institute of Surveyors and the Hong Kong Construction Industry Council.

Building a list of client organizations, however, proved more challenging, since almost every organization and individual is a potential client of the construction industry. Nevertheless, 
attempts were made to build a comprehensive list of clients; comprising public, private and quasi-public organizations. Again, the HKSAR Government construction related departments were the starting point. This was supplemented with snowball sampling using contractors and consultants as a source (c.f. Cheng et al., 2006) by searching their websites for the listing of their portfolio of clients. A total population of 1915 project organizations was drawn together from this exercise, compromising 137 client organizations, 1292 contractor organizations and 486 consultant organizations. A sample of 500 organizations (comprising 100 client, 250 contractor and 150 consultant organizations) was drawn from the population on the basis of expected response rates of surveys in the construction industry in Hong Kong (e.g. Phua, 2004, Anvuur, 2008) and the number of organizations from whom key contact persons could be identified.

A parallel questionnaire survey of client, consultant and contractor organizations was then conducted through the key contact persons who selected ongoing projects and administered the questionnaire to individuals working together in the same team on the same project. Based partially on pre-test results and cost considerations, each contact person was mailed a questionnaire pack containing a cover letter, five questionnaires and five FREEPOST return envelopes. The first administration yielded 232 responses (104 from contractors, 50 from consultants and 78 from clients). A second administration yielded a further 150 responses ( 70 from contractors, 44 from consultants and 36 from clients), giving a total of 382 individual responses from 115 organizations (52 contractor, 34 client and 29 consultant), a 23\% response rate. Upon examination of the responses, 39 respondents from 11 organizations initially classified as client organizations, were confirmed as working in dual roles as both client and consultant, representing a distinct group, subsequently referred to as "Dual Teams". A missing data pattern analysis resulted in the exclusion of 2 responses for excessive missing data (>50\%) (cf. Hair et al., 1998). The effective sample size for the analysis was, therefore, 
380 individuals nested in 115 project management teams. For cross-level relationships, subsample analysis was possible in addition to full sample analysis because of adequate sample sizes; however, at the team level, small sub-sample sizes did not allow for sub-sample analysis, therefore, only full sample analysis are undertaken at the team-level.

The double dispatch of the questionnaire also allowed for the checking of non-response bias, following Armstrong and Overton's (1977) time trend extrapolation procedure. The premise of this test is that differences between those who responded to the first dispatch and those who responded the second time closely reflect differences between respondents to the survey and non-respondents. A comparison of the first and second administration respondents however, showed no significant differences in age $\left(x^{2}=3.75, d f=4, p .>0.441\right)$, gender $\left(x^{2}=\right.$ $0.050, \mathrm{df}=1, \mathrm{p} .>0.824)$, education $\left(\mathrm{x}^{2}=7.46, \mathrm{df}=54, \mathrm{p} .>0.113\right)$, nationality $\left(\mathrm{x}^{2}=7.64, \mathrm{df}\right.$ $=6, \mathrm{p} .>0.266)$ or organizational $\operatorname{rank}\left(\mathrm{x}^{2}=53.50, \mathrm{df}=53, \mathrm{p} .>0.321\right)$. While the presence of non-response bias cannot be completely ruled out, it can be inferred from the above results that the sample is representative of the population. Overall, $53 \%$ of the respondents are older than 40 years, and $94 \%$ fall under the ranks of middle management $(40 \%)$, senior management (41\%) and director level (13\%). This distribution corresponds favourably to the target population of management level staff. Males make up $89 \%$ of the sample, nationals of Hong Kong and China combined make up $82 \%$ and persons of Chinese ethnicity make up $87 \%$. Average tenure in the construction industry is 17 years. In terms of education, $89 \%$ have a Bachelors degree or higher. Eighty-two per cent of the organizations employ 50 or more people. The average management team size is 10 persons. Contractors tended to have much larger project management teams (average size of 12), about twice the average team size for consultant and client organizations. The average number of responses from the 
organizations was four. Given that the average management team size was $10,40 \%$ of the management team members were sampled on the average, which is fairly representative.

\subsection{Measures}

Individual Psychological Empowerment was measured with the 12-item scale developed by Spreitzer (1995a), which measures the 4 sub-dimensions; meaning $(\alpha=.88)$, competence $(\alpha$ $=.91)$, self-determination $(\alpha=.82)$ and impact $(\alpha=.91)$. Team Psychological Empowerment was measured with Kirkman et al's (2004) 12-item scale, which measures the 4 subdimensions; potency, meaningfulness, autonomy and impact $(\alpha=.95)$.

Empowerment climate was assessed with an adapted version of the Conditions of Work Effectiveness Question-II (CWEQ-II) developed by Laschinger et al (2001). CWEQ-II is a 19-item scale comprising six sub-scales; access to opportunity $(\alpha=.86)$, information ( $\alpha$ $=.92)$, resources $(\alpha=.89)$, support $(\alpha=.85)$, formal power $(\alpha=.84)$ and informal power $(\alpha$ $=.86$ ). The original scale items for opportunity, formal power and informal power were maintained. Access to support, information and resources sub-scales were replaced with equivalent ones developed by Spreitzer (1996) which have greater face validity.

Team Interdependence was assessed with the 3-item scale $(\alpha=.74)$ of Liden et al. (1997). Leadership style was assessed with adaptations of two sub-scales measuring production orientation $(\alpha=.86)$ and consideration orientation $(\alpha=.89)$ from The Michigan Organizational Assessment Questionnaire (Cammann et al., 1979) which, respectively, reflect task and person related leadership styles. Span of control was measured using team/workgroup size as a proxy. Given the tendency for individuals to "fake good" in self-report surveys, we also measured social desirability using the 10-item short version of the MarloweCrowne 33-item scale of socially desirability proposed by Strahan and Gerbasi (1972). 


\subsection{Data analysis Strategy}

Two categories of hypotheses are proposed for testing. The first category comprise singlelevel relationships between variables at the team-level (i.e. Hypotheses H2a, b, c \& d; H3a, b, c \& d) while the second proposes cross-level relationships between variables at the teamlevel and variables at the individual-level (i.e. Hypotheses H1a, b, c and d). Thus, no single data analysis technique is appropriate for testing all the relationships. The single-level relationships between variables at the team-level were analysed using ordinary least square (OLS) regression while the cross-level relationships were analysed using Hierarchical Linear Modelling (HLM, Bliese and Hanges, 2004, Raudenbush and Bryk, 2002). HLM is the appropriate analysis technique for cross-level relationships and data that exhibit nonindependence.

Non-independence is the degree to which responses or observations of individuals are not independent as a result of being influenced by, depend on, or cluster by group membership due to co-location and shared experiences over time (Kenny and Judd, 1986, Kenny and Judd, 1996). This is often a consequence of high social interaction. Ignoring non-independence leads to bias in significant tests (Kenny and Judd, 1986) and loss of power (Bliese and Hanges, 2004). Using HLM for cross-level relationships allows the simultaneous modelling of the team-level predictors (e.g. team interdependence and span of control) and individuallevel outcomes (e.g. individual psychological empowerment) without having to aggregate or disaggregate both the predictors and outcomes to one level (Seibert et al., 2004, Hofmann, 1997). Non-independence in the data occurred because the data collection procedure, where individuals working together in the same team on the same project were sampled. Nonindependence renders statistical analysis techniques such as Analysis of Variance (ANOVA) and Ordinary Least Square (OLS) Regression inappropriate. This stems from their fundamental assumption that observations are independent (Raudenbush and Bryk, 2002). As 
the relationships delineated in Hypotheses H1a, b, c \& d are cross-level relationships between variables at the team-level (leadership style, team interdependence and span of control) and a variable at the individual-level (individual empowerment), HLM is the appropriate analysis technique to employ.

\section{RESULTS}

\subsection{Descriptive Statistics and Correlations}

The reliabilities and dimensionality of all multi-item measures were assessed by exploratory factor analysis using Principal Component Analysis with varimax rotation, as a preliminary measure to assert their validity. The scale items loaded as hypothesized or meaningfully and the measures also exhibited acceptable reliabilities as shown by their Chronbach's alphas in the diagonal of Table 1 which also shows the descriptive statistics and zero-order correlations among the variables. Apart from the correlations involving span of control and task orientated leadership style, the pattern of correlations among the other variables is consistent with the relationships delineated in the hypotheses above. All correlations are below 0.80 , the threshold of very high correlations when multicollinearity is obvious (Field, 2005). To further reduce the potential effect of multicollinearity, all variables were grand-mean centred (c.f. Hofmann, 1997). The correlations between the social desirability measure and team type 1contractor, task orientated leadership and team empowerment variables are higher than the threshold of between -0.20 and +0.20 suggested by Mitchell and Jolley (2001), an indication that social desirability bias strongly influences these measures and thus warrants controlling for in the analyses.

To justify aggregation of the team-level variables, James et al's (1984) interrater agreement index $\left(r_{\mathrm{WG}(J)}\right)$ and Burke, Finkelstein and Dusig's (1999) Average Deviation indexes (i.e. 
$\mathrm{AD}_{\mathrm{M}(\mathrm{J})}$ and $\mathrm{AD}_{\mathrm{Md}(\mathrm{J})}$ ) were calculated using the $\mathrm{R}$ software (available at www.r-project.org). The results for each of the 5 team-level variables are shown in Table 1. Significance tests show that there is acceptable agreement among team members, supporting aggregation. 
Table 1 Descriptive Statistics and Correlations

\begin{tabular}{|c|c|c|c|c|c|c|c|c|c|c|c|c|c|c|c|c|c|c|c|c|c|c|c|c|c|c|}
\hline & Variables & Mean & SD & $r_{\mathrm{wg}}$ & $\mathrm{AD}_{\mathrm{M}}$ & $\mathrm{AD}_{\mathrm{Md}}$ & 1 & 2 & 3 & 4 & 5 & 6 & 7 & 8 & 9 & 10 & 11 & 12 & 13 & 14 & 15 & 16 & 17 & 18 & 19 & 20 \\
\hline & Control Variables & & & & & & & & & & & & & & & & & & & & & & & & & \\
\hline 1 & Age & 0.53 & 0.50 & - & - & - & - & & & & & & & & & & & & & & & & & & & \\
\hline 2 & Gender & 0.89 & 0.31 & - & - & - & 0.09 & - & & & & & & & & & & & & & & & & & & \\
\hline 3 & Education & 0.43 & 0.50 & - & - & - & $0.21 *$ & -0.08 & - & & & & & & & & & & & & & & & & & \\
\hline 4 & Nationality & 0.82 & 0.39 & - & - & - & -0.10 & 0.02 & -0.09 & - & & & & & & & & & & & & & & & & \\
\hline 5 & Ethnicity & 0.87 & 0.34 & - & - & - & $0.11 \dagger$ & -0.03 & -0.03 & $0.66^{*}$ & - & & & & & & & & & & & & & & & \\
\hline 6 & Firm Size & 0.77 & 0.42 & - & - & - & 0.03 & 0.01 & -0.02 & 0.07 & 0.03 & - & & & & & & & & & & & & & & \\
\hline 8 & Team Type 1 (Contractor) & 0.46 & 0.50 & - & - & - & $-.016 \dagger$ & $0.22^{*}$ & $-0.25^{*}$ & 0.03 & -0.05 & 0.02 & 0.03 & - & & & & & & & & & & & & \\
\hline 9 & Team Type 2 (Client) & 0.20 & 0.40 & - & - & - & $0.14 \dagger$ & -0.01 & $0.20^{*}$ & -0.04 & -0.03 & $0.11^{\sim}$ & 0.06 & $-0.46^{*}$ & - & & & & & & & & & & & \\
\hline 10 & Team Type 3 (Dual) & 0.10 & 0.30 & - & - & - & 0.07 & -0.02 & 0.07 & 0.09 & 0.08 & $0.18^{*}$ & 0.08 & $-0.31 *$ & $-0.17 *$ & - & & & & & & & & & & \\
\hline 11 & Tenure (industry) & 16.89 & 8.46 & - & - & - & $0.79^{*}$ & 0.04 & $0.18^{*}$ & $-0.17 \dagger$ & 0.07 & -0.01 & 0.09 & -0.09 & 0.06 & 0.09 & - & & & & & & & & & \\
\hline 12 & $\begin{array}{l}\text { Number of Respondents } \\
\text { Leadership style }\end{array}$ & 4.00 & 2.00 & - & - & - & 0.06 & -0.07 & -0.08 & 0.09 & 0.06 & $0.23^{*}$ & $0.15 \dagger$ & 0.02 & -0.01 & $0.10^{\circ}$ & 0.03 & - & & & & & & & & \\
\hline 13 & Person Orientated & 3.71 & 0.57 & $0.83^{\sim}$ & 0.50 & $0.47 \dagger$ & 0.04 & 0.06 & -0.06 & 0.01 & -0.02 & 0.02 & -0.06 & -0.06 & -0.11 & -0.01 & -0.01 & -.02 & $(0.85)$ & & & & & & & \\
\hline 14 & $\begin{array}{l}\text { Task Orientated } \\
\text { Team Context }\end{array}$ & 3.34 & 0.50 & $0.87 \dagger$ & $0.42 \dagger$ & $0.33 \dagger$ & $0.14 \dagger$ & 0.04 & 0.02 & -0.00 & -0.06 & -0.02 & -0.02 & -0.17 & 0.04 & 0.01 & $0.11^{\sim}$ & 0.02 & $0.45^{*}$ & $(0.90)$ & & & & & & \\
\hline 15 & Span of Control & 9.39 & 6.96 & - & - & - & -0.03 & 0.09 & -0.05 & 0.09 & 0.04 & $0.28 \dagger$ & 0.13 & $0.34^{*}$ & -0.17 & -0.10 & -0.01 & 0.13 & -0.10 & -0.14 & - & & & & & \\
\hline 16 & $\begin{array}{l}\text { Team Interdependence } \\
\text { Empowerment }\end{array}$ & 3.57 & 0.45 & $0.87 \dagger$ & $0.44 \dagger$ & $0.33 \dagger$ & $0.19 \dagger$ & $0.13 \dagger$ & 0.00 & -0.05 & -0.07 & 0.15 & 0.09 & $-0.29^{\sim}$ & 0.15 & -0.04 & 0.10 & 0.03 & $0.37^{*}$ & $0.53^{*}$ & -0.05 & $(0.84)$ & & & & \\
\hline 17 & Individual Empowerment & 3.60 & 0.74 & - & - & - & $0.11^{\sim}$ & 0.08 & -0.02 & -0.08 & $-0.11^{\sim}$ & $-0.19^{*}$ & 0.00 & 0.04 & $-0.14 \dagger$ & -0.07 & $0.15^{*}$ & 0.03 & $0.38 \dagger$ & $0.34 \dagger$ & -0.01 & $0.32 \dagger$ & $(0.91-0.82)$ & & & \\
\hline 18 & Team Empowerment ${ }^{d}$ & 3.50 & 0.41 & $.96 \dagger$ & $0.44 \dagger$ & $0.36 \dagger$ & $0.13 \dagger$ & -0.06 & 0.02 & -0.08 & 0.12 & -0.07 & -0.03 & -0.09 & -0.05 & 0.09 & 0.12 & -0.06 & $0.66^{*}$ & $0.62^{*}$ & -0.10 & $0.59^{*}$ & $0.51 \dagger$ & $(0.95)$ & & \\
\hline 19 & $\begin{array}{l}\text { Empowerment Climate }^{\mathrm{d}} \\
\text { Social Desirability }\end{array}$ & 3.39 & 0.40 & $.84^{-}$ & $0.50^{\sim}$ & $0.45^{*}$ & 0.05 & -0.01 & -0.04 & -0.02 & 0.06 & -0.06 & -0.08 & $0.11^{\sim}$ & -0.04 & -0.03 & 0.04 & -0.06 & $0.52^{*}$ & $0.45^{*}$ & 0.05 & $0.39^{*}$ & $0.42 \dagger$ & $0.70^{*}$ & $(0.92-0.84)$ & \\
\hline 20 & Social Desirability & 5.95 & 1.56 & - & - & - & $0.17^{*}$ & $-010^{\sim}$ & $0.17^{*}$ & 0.07 & 0.03 & 0.07 & -0.04 & $-0.29 *$ & $0.20^{*}$ & 0.04 & $0.13 \dagger$ & 0.09 & 0.10 & $0.21 \dagger$ & $-0.17 \dagger$ & $0.19 \dagger$ & 0.05 & $0.23^{*}$ & $0.19^{*}$ & - \\
\hline
\end{tabular}

\section{NOTE: $\sim \mathrm{p}<0.05 ; \mathrm{i} p<0.01 ;{ }^{*} \mathrm{p}<0.001$.}

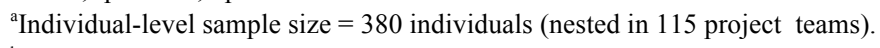

${ }^{\mathrm{b}} \mathrm{Chronbach}$ 's alphas are on the diagonal.

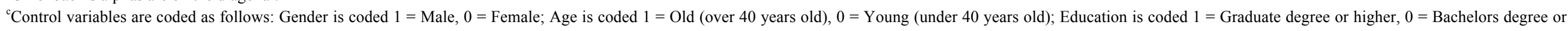

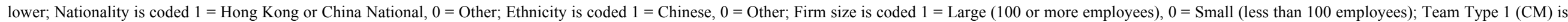
coded $1=$ Contractor, $0=$ Others; Team Type 2 (Client) is coded $1=$ Client, $0=$ Others and Team Type 3 (Dual) is coded $1=$ Dual $($ Client + Consultant), $0=$ Others, thus, Consultant is the reference in all cases

${ }^{\mathrm{d}}$ The team mean values of these variables are used, thus, correlations and significant tests associated with these variables should be viewed with caution.

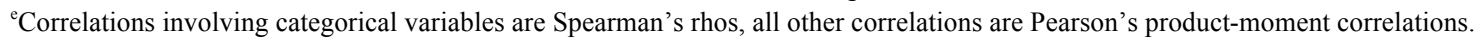

${ }^{\mathrm{f}}$ All variables except the social desirability measure and categorical variables, were scored on a 5-point Likert scale with higher scores indicating more of the construct. 
Table 2: HLM Analysis of Leadership Style and Team-context Impact on Individual Psychological Empowerment

\begin{tabular}{|c|c|c|c|c|c|}
\hline \multirow{4}{*}{ Variables } & \multicolumn{5}{|c|}{ Individual Psychological Empowerment } \\
\hline & Full & $\mathrm{CM}$ & PM & Client & Dual \\
\hline & Sample & Sample & Sample & Sample & Sample \\
\hline & 1 & 2 & 3 & 4 & 5 \\
\hline Gender & -0.07 & 0.10 & -0.14 & 0.08 & -0.28 \\
\hline Age & 0.07 & 0.07 & 0.06 & 0.05 & 0.19 \\
\hline Education & -0.03 & 0.00 & 0.00 & -0.13 & 0.17 \\
\hline Nationality & -0.05 & -0.04 & -0.19 & 0.10 & 0.20 \\
\hline Ethnicity & -0.14 & -0.18 & -0.26 & 0.13 & 0.40 \\
\hline Tenure (industry) & $0.01 * *$ & $0.01 *$ & $0.02 *$ & 0.01 & 0.03 \\
\hline Firm Size & $0.40 * * *$ & $0.51^{* * *}$ & 0.34 & 0.31 & - \\
\hline Firm Age & $\mathbf{0 . 0 0}$ & 0.00 & -0.00 & 0.00 & -0.01 \\
\hline Team Type $1(\mathrm{CM})$ & 0.15 & - & - & - & - \\
\hline Team Type 2 (Client) & 0.20 & - & - & - & - \\
\hline Team Type 3 (Dual) & -0.11 & - & - & - & - \\
\hline No respondents per team & 0.03 & 0.01 & 0.11 & 0.01 & 0.13 \\
\hline Social Desirability & -0.01 & 0.01 & -0.06 & 0.02 & 0.03 \\
\hline Task Orientated Leadership (H1a) & $0.15^{* * *}$ & $0.23 * *$ & \begin{tabular}{|l|}
-0.11 \\
\end{tabular} & 0.14 & 0.11 \\
\hline Person Orientated Leadership (H1b) & $0.30 * * *$ & 0.16 & $0.46 * * *$ & $0.31 * * *$ & $0.43 * * *$ \\
\hline Team Interdependence (H1c) & $0.37 * * *$ & $0.39 * * *$ & $0.53 * * *$ & $0.34 * *$ & 0.17 \\
\hline Span of control (H1d) & 0.00 & 0.00 & 0.01 & 0.02 & -0.03 \\
\hline \multicolumn{6}{|l|}{ Random Parameters } \\
\hline$\sigma^{2}$ & $0.14 * * *$ & $0.18^{* * *}$ & $0.08 * * *$ & $0.12 * * *$ & $0.19 * *$ \\
\hline$\tau_{00}$ & $0.12 * * *$ & 0.04 & $0.22 * *$ & $0.23^{*}$ & 0.01 \\
\hline$R_{1}^{2}$ & 0.53 & 0.60 & 0.49 & 0.33 & 0.43 \\
\hline$\Delta R_{1}^{2}$ (Unique) & 0.46 & 0.49 & 0.44 & 0.33 & 0.43 \\
\hline$\Delta$ Deviance & $288.19 * * *$ & $104.68 * * *$ & $78.67 * * *$ & $46.33 * * *$ & 8.14 \\
\hline
\end{tabular}

NOTE: ${ }^{*} p<0.05 ; * * p<0.01 ; * * * p<0.001$.

${ }^{\text {a }}$ Sample sizes for Full sample, CM (i.e. Contractor), PM (i.e. Consultant), Client and Dual sub-samples are respectively 380, 174, 92, 75 and 39. Given the small sample sizes for the Client and Dual sub-samples the results for these sub-samples should be viewed with caution.

${ }^{\mathrm{b}} \mathrm{Control}$ variables are coded as follows: Gender is coded $1=$ Male, $0=$ Female; Age is coded $1=$ Old (over 40 years old), $0=$ Young (under 40 years old); Education is coded $1=$ Graduate degree or higher, $0=$ Bachelors degree or lower; Nationality is coded $1=$ Hong Kong or China National, $0=$ Other; Ethnicity is coded $1=$ Chinese, $0=$ Other; Firm size is coded $1=$ Large ( 100 or more employees), $0=$ Small (less than 100 employees); Team Type $1(\mathrm{CM})$ is coded $1=$ Contractor, $0=$ Others; Team Type 2 (Client) is coded $1=$ Client, $0=$ Others and Team Type 3 (Dual) is coded $1=$ Dual, $0=$ Others, thus, Consultant is the reference in all cases 


\subsection{Tests of Hypotheses}

For all cross-level analyses, age, gender, education, nationality, ethnicity, firm size and age, tenure and organization type as well as social desirability were included as control variables due to their possible confounding effects on the relationships (c.f. Dimitriades and Kufidu, 2004, Kanter, 1977, Spreitzer, 1995b, Spreitzer et al., 1997). Similarly, firm size and age, number of respondents per team, organization type and social desirability were also included as control variables in all team-level analyses. Given the large number of control variables, we examined the shared variance between the predictor variables of interest and the control variables in accord with Breaugh (2008), to check over control of predictor variance. The results show that only $7 \%$ of the variance in individual psychological empowerment is shared with the control variables, $5 \%$ for empowerment climate and 3\% for team psychological empowerment. This suggests that on average, $95 \%$ of the original construct is still reflected in the residual predictors. Thus, lack of construct validity from over control should not be an issue in the analyses.

Tests of Hypotheses Hla, $b, c \& d$

Table 2 presents a summary of the analysis to test Hypotheses H1a, b, c \& d. In the full sample (i.e. model 1), span of control is not significantly related to individual psychological empowerment ( $\beta=0.00$, ns), while team interdependence is positively and significantly related $(\beta=0.37, \mathrm{p}<0.001)$. Also, while task orientated leadership and person orientated leadership were expected to, respectively, relate negatively and positively to individual psychological empowerment they both emerged positively and significantly related to individual psychological empowerment (i.e. $\beta=0.15, \mathrm{p}<0.001$, for task orientated leadership and $\beta=0.30, p<.001$, for person orientated leadership). Together, the four variables explain $46 \%$ of variance in individual psychological empowerment. 
The sub-sample analysis illuminates the full sample findings regarding the role of leadership in engendering individual psychological empowerment. The results indicate that only in the contractor (CM) sub-sample is task orientated leadership positively and significantly related to individual psychological empowerment (i.e. model $2 ; \beta=0.23, p<0.01$ ). On the other hand, person orientated leadership is positively and significantly related to individual psychological empowerment in the consultant $(\mathrm{PM})$ (i.e. model 3; $\beta=0.46, \mathrm{p}<0.001$ ), client (i.e. model 4; $\beta=0.31, \mathrm{p}<0.001$ ) and dual (i.e. model $5 ; \beta=0.43, \mathrm{p}<0.001$ ) sub-samples. Taken together, Hypotheses H1a and H1d are not supported in the full sample or the subsample analysis, while Hypothesis H1b is supported in the full sample, consultant, client and dual sub-samples but not in the contractor sub-sample. Hypothesis H1c is also supported in the full sample, contractor, consultant and client sub-samples but not in the dual sub-sample. However, given the small sample size for the dual sub-sample, these results should be viewed with caution.

Tests of Hypotheses $H 2 a, b, c \& d$

Model 2 (Table 3) shows the results of the impact of the leadership style and team-context factors on team psychological empowerment, tests of Hypotheses H2a-d. The results are a direct replication of the full sample results (Model 1, Table 2) for the impact of leadership style and team-context factors on individual psychological empowerment. While span of control has no significant relationship with team psychological empowerment $(\beta=0.00, \mathrm{~ns})$, team interdependence $(\beta=.32, p<.001)$, task orientated $(\beta=.19, p<.001)$ and person orientated $(\beta=.35, p<.001)$ leadership styles are positively and significantly related to team psychological empowerment. Together, they explain a unique variance of $56 \%$ in team psychological empowerment. Thus, while Hypotheses H2a \& d are not supported, Hypotheses H2b \& c are supported. 
Table 3: OLS Regression Analysis of Leadership Style and Team-context Impact on Team Psychological Empowerment and Empowerment Climate

\begin{tabular}{|c|c|c|c|}
\hline \multirow{3}{*}{ Variables } & & $\begin{array}{l}\text { Team } \\
\text { Psychological } \\
\text { Empowerment }\end{array}$ & $\begin{array}{l}\text { Empowerment } \\
\text { Climate }\end{array}$ \\
\hline & \multicolumn{3}{|c|}{ Full Sample } \\
\hline & 1 & 2 & 3 \\
\hline Firm Size & -0.11 & $-0.13 *$ & $-0.18 *$ \\
\hline Firm Age & 0.00 & 0.00 & 0.00 \\
\hline Team Type $1(\mathrm{CM})$ & $0.21 *$ & 0.11 & $0.28 * * *$ \\
\hline Team Type 2 (Client) & 0.02 & -0.04 & 0.18 \\
\hline Team Type 3 (Dual) & 0.04 & $0.20 *$ & 0.17 \\
\hline No of respondents per team & -0.02 & -0.02 & -0.02 \\
\hline Social Desirability & $0.09 * *$ & 0.03 & $0.06^{*}$ \\
\hline Task Orientated Leadership (H2a \& 3a) & & $0.19 * * *$ & 0.13 \\
\hline Person Orientated Leadership (H2b \& 3b) & & $0.35 * * *$ & $0.37 * * *$ \\
\hline Team Interdependence (H2c \& 3c) & & $0.32 * * *$ & 0.13 \\
\hline Span of control $(\mathrm{H} 2 \mathrm{~d} \& \mathrm{3d})$ & & $\mathbf{0 . 0 0}$ & 0.01 \\
\hline$R^{2}$ & 0.10 & 0.65 & 0.45 \\
\hline$\Delta R^{2}$ & 0.10 & 0.56 & 0.35 \\
\hline F Change & 1.58 & $38.47 * * *$ & $15.34 * * *$ \\
\hline Durban-Watson test & & 2.14 & 2.03 \\
\hline$A N O V A(F)$ & 1.58 & $16.23 * * *$ & $7.15 * * *$ \\
\hline Adjusted $R^{2}$ & 0.04 & 0.61 & 0.39 \\
\hline Unique Variance of Antecedents & 0.04 & 0.56 & 0.35 \\
\hline
\end{tabular}

NOTE: *p<0.05;**p $<0.01 ; * * * p<0.001$

${ }^{\text {a }}$ Team-level sample size $=115$ (comprising 52 Contractor, 29 Consultant, 23 Client and 11 Dual project teams), due to the small sub-sample sizes, results are only reported for the full sample analysis.

${ }^{\mathrm{b}}$ Variables are coded as follows: Firm size is coded $1=$ Large (100 or more employees), $0=$ Small (less than 100 employees); Team Type $1(\mathrm{CM})$ is coded $1=$ Contractor, $0=$ Others; Team Type 2 (Client) is coded $1=$ Client, $0=$ Others and Team Type 3 (Dual) is coded $1=$ Dual (Client + Consultant), $0=$ Others (i.e. Consultant is the reference)

Tests of Hypotheses H3a, $b, c \& d$

The results of the impact of the team context on empowerment climate are shown in model 3 (Table 3) and indicate that only person orientated leadership style is positively and significantly related to empowerment climate $(\beta=.37, p<.001)$ while task orientated 
leadership $(\beta=0.13, \mathrm{~ns})$, team interdependence $(\beta=0.13, \mathrm{~ns})$ and span of control $(\beta=0.01$, ns) are not significantly related to empowerment climate. The variables, however, together explain a unique variance of $35 \%$ in empowerment climate. Thus, while Hypothesis H3b is supported, Hypotheses H3a, c and d are not supported.

\section{DISCUSSION}

The analyses employing the full/combined and sub-samples reveal both expected and unexpected results. The results show that high interdependence and both high person and task orientated leadership styles are related to both high individual and team psychological empowerment. However, only high person orientated leadership style is related to more empowering work climate. This partially supports the findings of Nauman et al (2010) who report a positive and significant relationship between both task and person orientated leadership styles and empowerment climate. The differences in the findings of the two studies can be attributed to the differences in the context of the studies; IT projects (more and less virtual contexts) in Nauman et al's study and construction project context of this study. The differences may also be linked to the different operationalization of both empowerment climate and leadership styles measures.

Span of control has no significant association with any of the facets of empowerment while team interdependence is also not related to empowerment climate. The emergence of interdependence as a key antecedent of psychological empowerment is not surprising. Tesluk et al. (1997) highlight the importance of task interdependence in the implementation of teambased interventions. In accord, Chen et al. (2007) found stronger support for several hypothesized relationships involving psychological empowerment and performance outcomes 
in high interdependence teams, but somewhat weaker support in low interdependence teams; thereby confirming team interdependence as a critical boundary condition.

A surprising finding in the full sample analysis is that both high task and person orientated leadership are associated with high psychological empowerment, contrary to the expectation that high task orientated leadership is related to low levels of psychological empowerment and high person orientated is associated with high levels of psychological empowerment. This finding however adds to the growing evidence for lack of support for the stereotypical views on the outcomes and manifestations of task and person orientated leadership (c.f. Orton, 2000, Wong et al., 2007, Vinkenburg et al, 2011). For example, in a Hong Kong study, Wong et al. (2007) found no differences in the level of task and person orientated leadership exhibited by expatriate and Chinese project managers, contrary to the conventional wisdom that Western managers are more task orientated while their Chinese counterparts are more person orientated. Wong et al. suggest that "a 'third leadership style' which equally considers the importance of task performance and interpersonal relationships might also exist in the multinational construction firms in Hong Kong” (2007: 102). A plausible explanation for these findings is the notion of "leadership adjustment" (c.f. Festing and Maletzky, 2011), similar to what has become known as "intercultural adjustment" (c.f. Brew and Cairns, 2004) in cross-cultural studies, in which expatriate managers modify their behaviours (e.g. regarding communication and conflict management) to suit their host country's culture. Here, however, the suggested adjustment is in terms of the demands of the project context. Successful project delivery dependents on acts required to "getting the job done" as well as "teamwork behaviours" that promote cooperation and collaboration. The need for both leadership styles in accomplishing this mutual goal is apparent. Project participants and leaders may, therefore, be accustomed to or may have adjusted to both task and person leadership in recognition of the need for both leadership styles in the project delivery process. 
This view of a hybrid leadership style is consistent with the sociotechnical systems theory and emphasizes the joint optimisation of the technical and social sub-systems for the achievement of unit goals (c.f. Trist and Bamforth, 1951) especially in team context and also resonates with situational/contingency perspective of leadership as a dynamic process (c.f. Hersey and Blanchard, 1982).

The findings from the sub-sample analyses are illuminating. They show that in client, consultant and dual teams only person orientated leadership is significantly associated with individual psychological empowerment, while in contractor organizations only task orientated leadership is significantly associated with individual psychological empowerment. A plausible explanation can be drawn from Walker's (2002) systems perspective of project organization in which, at a general level, the client and his/her representatives (in this case consultant and dual teams) constitute the managing sub-system concerned with decisionmaking, maintenance and regulatory activities (i.e. integration and control) while the contractor's team constitutes the operating or task sub-system concerned with carrying out the professional and technical tasks required for project execution. The success of the managing sub-system is, to a large extent, rooted in the successful management of interrelationships (i.e. person orientated leadership) while the success of the operating or task sub-system lies in task performance (i.e. task orientated leadership).

This line of argument is supported by the findings from a comparative study of the organizational cultures of architects and contractors by Ankrah and Langford (2005). Their findings show that architectural practices (consultants) are, largely, informal organizations in which control and coordination are achieved through empathy and direct personal contact among organizational members (i.e. person orientated leadership). Pertaining to contractors, however, their findings reveal that although there are also informal systems, control and coordination are achieved through formal methods and procedures (i.e. task orientated 
leadership). In support, Fellows et al. (2003) suggest that consultants are process orientated while contractors are more outcome orientated. An earlier study in Hong Kong by Rowlinson et al. (1993) also found that, project managers and leaders in design teams (consultants) generally exhibited relationship based leadership, while their counterparts in construction organizations (contractors) displayed a range of leadership styles including both task and person orientated leadership. Earlier studies of leadership in the construction context in the UK by Bresnen et al. (1986) also found site managers exhibiting stronger task orientated leadership styles. However, Fellows et al. (2003) found that, in Hong Kong, relationship orientation of project quantity surveyors is stronger among contractors than consultants. Taken together, there is greater consistency between prior findings pertaining to the effectiveness of the different leadership styles and that found in this study and, thus, suggests that, contrary to conventional wisdom, task orientated leadership style is not necessarily disempowering.

\section{CONCLUSIONS}

The role of the team or work-unit as a social environment for interaction that shapes individual behaviour, attitudes and perceptions was the focus of this study. High interdependence and both high person and task orientated leadership styles are related to high psychological empowerment in general as a result of leadership adjustment to changing project demands in order to accomplish the mutual goal of "getting the job done" and "teamwork" in project delivery. Span of control, however, has no association with psychological or structural empowerment. Leadership styles have distinctive effects on structural and psychological empowerment especially in client, consultant and contractor organizations. Person orientated leadership results in high psychological empowerment in client related organizational teams whose project role (i.e. managing sub-system) is better accomplished through the successful management of interrelationships and empathy. 
However, in contractor organizational teams, task orientated leadership results in high psychological empowerment as the contractor's project role (i.e. operating or task sub-system) is better accomplished through formal methods and procedures of task performance.

These findings have theoretical and practical implications for empowerment and leadership in projects, in particular, and project management in general. The study makes a significant contribution to empowerment theory in two fronts. First, it adds to our understanding of the important team-level influences on empowerment perceptions. This is important in view of Loosemore et al's (2003) assertion that empirical examination of factors that impact empowerment in the construction management domain in particular is rare, a feature that retards efforts to develop strategies to foster empowerment and performance in projects. Second, the study helps advance empowerment theory regarding its multi-faceted nature. While previous studies have taken a unitary perspective of empowerment, this study examined three facets of empowerment (i.e. individual and team psychological empowerment and empowerment climate) and showed that more targeted interventions may be required to foster empowerment in projects since the different facets, especially psychological and empowerment climate, are impacted by different factors. However, from a multi-level perspective the findings are supportive of the isomorphic view of psychological empowerment as the findings in relation to individual psychological empowerment were replicated with regards to team psychological empowerment.

Theoretically, the findings also support the existence of the notion of "leadership adjustment" (c.f. Festing and Maletzky, in press), similar to what has become known as "intercultural adjustment" (c.f. Brew and Cairns, 2004), and suggests that leaders may need to juggle between task and person orientated leadership in projects. This can therefore provide preliminary evidence for future studies to explore how leadership adjustment can better be employed and the circumstances under which it produces more effective outcomes. This 
confirmation is important as the conventional wisdom up until now was that task orientated leadership is disempowering.

Methodologically, the findings of the sub-sample analyses suggest that construction management researchers must give much greater thought to the selection of samples in the design of studies and be aware that their findings may not necessarily generalise across client, consultant and contractor organizations. Considering construction and project organizations as a homogeneous sample can, therefore, result in erroneous findings and false conclusions.

There are also practical implications for the deployment and training of leaders in project organizations and the range of competencies required in successful project leadership and delivery, especially within the context of increasing internationalization of construction and project organizations. The findings particularly imply that leaders must develop dynamic capabilities that can enable them to juggle both task and person orientated leadership styles and respond proactively to changing project demands in order to continuously motivate individuals and teams in successful project delivery. The findings with regards to different leadership effects in consultant, contractor, client and dual teams also have practical implications regarding managing across boundaries in projects. Leaders in projects are increasing involved in boundary spanning activities which often require them to lead teams across organizational, national and ethnic boundaries (cross-functional teams). Thus, while the findings show that contractors' project managers may be more successful in leading and empowering their internal teams through task orientated leadership styles, such project managers will be required to juggle between both task and person orientated leadership when involved in managing problem solving teams across boundaries in projects where team members are often drawn from the contractor, consultant and client organisations (i.e. crossfunctional teams). 
The study however has several limitations. First, its cross-sectional nature precludes inferring causality. Thus, as others suggest, empowerment may as well promote effective leadership and not the other way round as proposed here and prior studies (Nauman et al, 2010). Second, the small sub-sample sizes at the team-level, precluded any meaningful exploration of the relationships in the separate sub-samples at the team level for any subtle differences, especially that team (organization) type dummy variables were consistently significant in most of the models. Thirdly, the study focussed on project management-level staff due to their strategic role in the project delivery process. It will however be interesting to examine the impact of leadership on the empowerment perceptions of front-line staff. Given their lower formal power at the project level, psychological empowerment may even be a more important driver of performance for them (Tuuli, 2009). Lastly, the paper is also limited in terms of the scope of leadership perspectives examined. While a behavioural perspective of leadership was examined in this study, the dominant perspective on leadership studies in projects (Toor and Ofori, 2008c), others have highlighted the importance of other perspectives of leadership such as leadership development (e.g. Toor and Ofori, 2008a) transformational leadership (e.g. Keegan and Den Hartog, 2004), emotional aspects of leadership (e.g. Butler and Chinowsky, 2006), competency perspectives (e.g. Muller and Turner, 2007, Debrah and Ofori, 2005) and authentic leadership (e.g. Toor and Ofori, 2008b) in project delivery and could therefore be considered in future studies to establish their empowering nature and thereby capture a more complete body of knowledge on the impact of leadership on empowerment perceptions.

Finally, interdependence and leadership style emerge as critical factors in engendering facets of empowerment in project teams, albeit differently, and are therefore concrete targets for organizations and leaders desirous of promoting empowerment. This study provides fertile avenues for further research focusing on identifying other antecedents of empowerment at the 
team level but also at the individual, organization and project levels. Future research may also consider the interactive or combinative effect of task and person orientated leadership behaviours; as Casmir and $\mathrm{Ng}$ (2010) suggest that leadership style outcomes may depend on how task and person orientated leadership styles are combined (i.e. additive or interactive). A much wider consideration of scope of leadership (e.g. leadership development, transformational leadership, emotional aspects of leadership, competency perspectives and authentic leadership) also present fertile avenues for future research.

\section{REFERENCES}

Anderson, N. R. \& West, M. A. (1998), “Measuring climate for work group innovation: development and validation of the team climate inventory", Journal of Organizational Behaviour, Vol. 19 No. 3, pp. 235-258.

Anvuur, A. M. (2008), Cooperation in construction projects: Concept, antecedents and strategies, $\mathrm{PhD}$ Thesis, Department of Civil Engineering, The University of Hong Kong, Hong Kong.

Ankrah, N. A. \& Langford, D. A. (2005), “Architects and contractors: A comparative study of organizational cultures", Construction Management \& Economics, Vol. 23 No 6, pp. 595-607.

Antonakis, J. \& Atwater, L. (2002), "Leader distance: A review and a proposed theory", The Leadership Quarterly, Vol. 13 No. 6, pp. 673-704.

Armstrong, J. S. \& Overton, T. S. (1977), "Estimating non-response bias in mail surveys", Journal of Marketing Research, Vol. 14 No. 3, pp. 396-402.

Bass, B. M. (1985), Leadership and performance beyond expectations, New York: Free Press. 
Blake, R. R. \& Mouton, J. S. (1964), The managerial grid: key orientations for achieving production through people, Houston, Texas: Gulf Publishers.

Blanchard, K., Carlos, J. P. \& Randolph, A. (1999), The 3 keys to empowerment : release the power within people for astonishing results, 1st Edn. Berrett-Koehler Publishers, San Fransico.

Bliese, P. D. \& Hanges, P. J. (2004), "Being both too liberal and too conservative: The perils of treating grouped data as though they were independent", Organizational Research Methods, Vol. 7 No. 4, pp. 400-417.

Bowen, D. E. \& Lawler, E. E. (1992), “The empowerment of service workers: what, why, how, and when”, Sloan Management Review, Vol. 33 No. 3, pp. 31-40.

Bresnen, M. J., Bryman, A. E., Ford, J. R., Beardsworth, A. D. \& Keil, E. T. (1986), "Leader orientation of construction site managers", Journal of Construction Engineering and Management, Vol. 112 No. 3, pp. 370-385.

Breaugh, J. A. (2008), "Important considerations in using statistical procedures to control for nuisance variables in non-experimental studies", Human Resource Management Review, Vol. 18 No. 4, pp. 282-293.

Brew, F. P. \& Cairns, D. R. (2004), "Do culture or situational constraints determine choice of direct or indirect styles in intercultural workplace conflicts?", International Journal of Intercultural Relations, Vol. 28 No. 5, pp. 331-352.

Bryman, A., Bresnen, M., Beardsworth, A. D., Ford, J. \& Keil, E. T. (1987), “The concept of the temporary system: The case of the construction project”, in Di Thpmaso, N. \& Bacharach, S. (Eds.), Research in the sociology of organizations, JAI Press, Greenwich, pp. 253-283. 
Butler, C.J. and Chinowsky, P.S. (2006), "Emotional intelligence and leadership behaviour in construction executives”, Journal of Management in Engineering, Vol. 22 No. 3, pp. 119-25.

Burke, M. J., Finkelstein, L. M. \& Dusig, M. S. (1999), “On average deviation indices for estimating interrater agreement", Organizational Research Methods, Vol. 2 No. 1, pp. 49-68.

Cammann, C., Fichman, M., Jenkins, D. \& Klesh, J. (1979), The Michigan organizational assessment questionnaire, University of Michigan, Ann Arbor, Michigan: Unpublished Manuscript.

Casmir, G. \& Ng, Y. N. K. (2010), “Combinative aspects of leadership style and the interaction between leadership behaviours". Leadership \& Organization Development Journal, Vol. 31, pp. 501-517.

Chen, G. \& Kanfer, R. (2006), “Toward a systems theory of motivated behaviour in work teams", in Staw, B. M. (Ed.) Research in Organizational Behaviour,. Oxford: JAI, pp. 223-267.

Chen, G., Kirkman, B. L., Kanfer, R., Allen, D. \& Rosen, B. (2007), “A multilevel study of leadership, empowerment and performance in teams", Journal of Applied Psychology, Vol. 92 No. 2, pp. 331-346.

Cheng, J., Proverbs, D. G. \& Oduoza, C. F. (2006), “The satisfaction levels of UK construction clients based on the performance of consultants: Results of a case study", Engineering, Construction and Architectural Management, Vol. 13 No. 6, pp. 567583.

Conger, J. A. \& Kanungo, R. N. (1988), “The empowerment process: Integrating theory and practice", Academy of Management Review, Vol. 13 No. 3, pp. 471-482. 
Debrah, Y.A. and Ofori, G. (2005), "Emerging managerial competencies of professionals in the Tanzanian construction industry", Human Resource Management, Vol. 16 No. 8, pp. 1399-414.

Dulewicz, V. and Higgs M. J. (2003). "Design of a new instrument to assess leadership dimensions and styles", Henley Working Paper Series HWP 0311, Henley-on-Thames, UK: Henley Management College.

Dimitriades, Z. \& Kufidu, S. (2004), "Individual, job, organizational and contextual correlates of employment empowerment: Some Greek evidence”, Electronic Journal of Business Ethics and Organization Studies, Vol. 9 No. 2, pp. 36-43.

Eylon, D. \& Bamberger, P. (2000), "Empowerment cognitions and empowerment acts: Recognising the importance of gender", Group \& Organization Management, Vol. 25 No. 4, pp. 354-372.

Fellows, R., Liu, A. M. M. \& Fong, C. M. (2003), "Leadership style and power relations in quantity surveying in Hong Kong”, Construction Management \& Economics, Vol. 21 No. 8 , pp. 809-818.

Festing, M. \& Maletzky, M. (in press), “Cross-cultural leadership adjustment -- A multilevel framework based on the theory of structuration", Human Resource Management Review.

Field, A. P. (2005) Discovering statistics using SPSS : (and sex, drugs and rock'n'roll), 2nd Edn. SAGE, London.

Fleishman, E. A., Mumford, M. D., Zaccaro, S. J., Levin, K. Y., Korotkin, A. L. \& Hein, M. B. (1991), "Taxonomic efforts in the description of leader behaviour: A synthesis and functional interpretation”, Leadership Quarterly, Vol. 2 No. 4, pp. 245-287. 
Forrester, R. (2000), “Empowerment: Rejuvenating a potent idea”, Academy of Management Executive, Vol. 14 No. 3, pp. 67-80.

French, J. R. P., Raven, B. (1959), “The Bases of Social Power”, in Cartwright, D. (Ed), Studies in Social Power, Ann Arbour: Institute for Social Research, University of Michigan.

Goleman, D., Boyatzis, R. E. and McKee, A. (2002). The new leaders. Cambridge (MA), Harvard Business School Press.

Greasley, K., Bryman, A., Dainty, A. R. J., Price, A. D. F., Soetanto, R. \& King, N. (2005), “Employee perceptions of empowerment”, Employee Relations, Vol. 27 No. 4, pp. 354-368.

Hair, J. F., Anderson, R. E., Tatham, R. L. \& Black, W. C. (1998), Multivariate data analysis, 4th Edn. Prentice Hall, Upper Saddle River, N.J.

Hardy, C. \& Leiba-O'Sullivan, S. (1998), “The power behind empowerment: Implications for research and practice", Human Relations, Vol. 51 No. 4, pp. 451-483.

Hersey, P. \& Blanchard, K. H. (1982), Management of organizational behaviour: Utilising human resources, London: Prentice-Hall.

Hofmann, D. A. (1997), “An overview of the logic and rationale of hierarchical linear models", Journal of Management, Vol. 23 No. 6, pp. 723-744.

Hofstede, G.H. (2001), Culture's Consequences: Comparing Values, Behaviors, Institutions, and Organizations Across Nations (2 edn.), Thousand Oaks, CA: Sage.

Hofstede, G.H., Hofstede, G.J., \& Minkov, M. (2010), Cultures and Organizations: Software of the mind (3 Edn.), New York: McGraw-Hill. 
James, L. R., Demaree, R. G. \& Wolf, G. (1984), “Estimating within-group inter-rater reliability with and without bias”, Journal of Applied Psychology, Vol. 69 No. 1, pp. $85-98$.

Jung, D. I. and J. J. Sosik (2002). "Transformational leadership in work groups: The role of empowerment, cohesiveness, and collective-efficacy on perceived group performance." Small Group Research Vol. 33 No. 3, pp. 313-336.

Kanter, R. M. (1977), Men and women of the corporation, 1st Edn. Basic Books, New York. Kanter, R. M. (1993), Men and women of the corporation, 2nd Edn. Basic Books, New York. Katz, D., Maccoby, N. \& Morse, N. C. (1987), Productivity, supervision, and morale in an office situation, New York: Garland.

Keegan, A. E. and Den Hartog, D. N. (2004), "Transformational leadership in a project-based environment: a comparative study of the leadership styles of project managers and line managers", International Journal of Project Management, Vol. 22 No. 8, pp. 609-617.

Keller, T. and Dansereau, F. (1995), "Leadership and empowerment: A social exchange perspective", Human Relations, Vol. 48 No. 2, pp. 127-146.

Kenny, D. A. \& Judd, C. M. (1986), "Consequences of violating the independence assumption in analysis of variance”, Psychological Bulletin", Vol. 99 No. 3, pp. $422-$ 431.

Kenny, D. A. \& Judd, C. M. (1996), “A general procedure for the estimation of interdependence", Psychological Bulletin, Vol. 119 No. 1, pp. 138-148.

Kirkman, B. L. \& Rosen, B. (1997), “A model of work team empowerment”, in Pasmore, W. A. \& Woodman, R. W. (Eds), Research in organizational change and development, JAI Press, England, pp. 131-167. 
Kirkman, B. L. \& Rosen, B. (1999), “Beyond self-management: Antecedents and consequences of team empowerment", Academy of Management Journal, Vol. 42 no. 1, pp. 58-74.

Kirkman, B. L., Rosen, B., Tesluk, T. \& Gibson, C. (2004), “The impact of team empowerment on virtual team performance: The moderating role of face-to-face interaction", Academy of Management Journal, Vol. 47 No. 2, pp. 175-192.

Klein, K. J. \& Kozlowski, S. W. J. (2000), Multilevel theory, research, and methods in organizations: foundations, extensions, and new directions, 1st Edn. Jossey-Bass, San Francisco, California.

Laschinger, S. H. K., Finegan, J., Shamian, J. \& Wilk, P. (2001), "Impact of structural and psychological empowerment on job strain in nursing work settings: expanding Kanter's model", Journal of Nursing Administration, Vol. 31 No. 5, pp. 260-272.

Lawler, E. E. (1992) The ultimate advantage: Creating the high-involvement organization, San Francisco, California: Jossey-Bass.

Lewin, K. (1947), "Frontiers in group dynamics: Concept, method and reality in social science, social equilibrium and social change", Human Relations, Vol. 1 No. 1, pp. 541.

Liden, R. C. \& Arad, S. (1996), “A power perspective of empowerment and work groups: Implications for human resources management research", in Ferris, G. R. (Ed) Research in personnel and human resources management, London: JAI Press.

Liden, R. C., Wayne, S. J. \& Bradway, L. K. (1997), “Task interdependence as a moderator of the relation between group control and performance", Human Relations, Vol. 50 No. 2, pp. 169-181. 
Mathieu, J. E., Gilson, L. L. \& Ruddy, T. R. (2006), “Empowerment and team effectiveness: An empirical test of an integrated model”, Journal of Applied Psychology, Vol. 91 No. 1, pp. 97-108.

Menon, S. T. (1999), "Psychological empowerment: definition, measurement, and validation”, Canadian Journal of Behavioural Science, Vol. 31 No. 3, pp. 161-164.

Menon, S. (2001), “Employee empowerment: An integrative psychological approach”, Applied Psychology, Vol. 50 No. 1, pp. 153-180.

Mills, P. K. \& Ungson, G. R. (2003), "Reassessing the limits of structural empowerment: Organizational constitution and trust as controls", Academy of Management Review, Vol. 28 No. 1, pp. 143-153.

Mitchell, M. \& Jolley, J. (2001) Research design explained, 4th Edn. Harcourt College Publishers, Fort Worth, TX.

Muller, R. and Turner, J. R. (2007), "Matching the project manager's leadership style to project type", International Journal of Project Management, Vol. 25, No. 1, pp. 21-32.

Mwaura, G., Sutton, J., \& Roberts, D. (1998), "Corporate and national culture - an irreconcilable dilemma for the hospitality manager?", International Journal of contemporary Hospitality Management, Vol. 10 No. 6, pp. 212-220.

Nauman, S., Mansur Khan, A. \& Ahsan, N. (2010), "Patterns of empowerment and leadership style in project environment", International Journal of Project Management, Vol. 28 No. , 638-649.

Orton, J. (2000), Key to successful Intercultural communication between partners in Australian-Chinese joint ventures, Richardmord, Victoria, Australia: The Australia China Business Council. 
Ouchi, W. G. \& Dowling, J. B. (1974), "Defining the span of control", Administrative Science Quarterly, Vol. 19 No. 3, pp. 357-365.

Phua, F. (2004), Improving construction cooperation : New theoretical insights into how and why, Research Studies Press, Baldock, Hertfordshire.

Quinn, R. E. \& Spreitzer, G. M. (1997), “The road to empowerment: Seven questions every leader should consider", Organizational Dynamics, Vol. 26 No. 2, pp. 37-49.

Raudenbush, S. W. \& Bryk, A. S. (2002), Hierarchical linear models: Applications and data analysis methods, Thousand Oaks, California: Sage Publications.

Reichers, A. E. \& Schneider, B. (1990), “Climate and culture: An evolution of constructs”, in Schneider, B. (Ed), Organizational climate and culture,. Jossey-Bass, San Francisco, pp. 5-39.

Rowlinson, S. M., Ho, T. K. K. \& Po-Hung, Y. (1993), "Leadership style of construction managers in Hong Kong", Construction Management \& Economics, Vol. 11 No. 6, pp. $455-465$.

Saavedra, R., Earley, P. C. \& Van Dyne, L. (1993), “Complex interdependence in taskperforming groups", Journal of Applied Psychology, Vol. 78 No. 1, pp. 61-72.

Seibert, S. E., Silver, S. R. \& Randolph, W. A. (2004), “Taking empowerment to the next level: A multiple-level model of empowerment, performance, and satisfaction.”,Academy of Management Journal, Vol. 47 No. 3, pp. 332-349.

Seibert, S. E., Wang, G. \& Courtright, S. H. (2011), "Antecedents and Consequences of Psychological and Team Empowerment in Organizations: A Meta-Analytic Review", Journal of Applied Psychology, Vol. 96 No. 5, pp. 981-1003. 
Skipper, C.O. and Bell, L.C. (2006a), “Assessment with 3608 evaluations of leadership behaviour in construction project managers", Journal of Management in Engineering, Vol. 22 No. 2, pp. 75-80.

Skipper, C.O. and Bell, L.C. (2006b), "Influences impacting leadership development", Journal of Management in Engineering, Vol. 22 No. 2, pp. 68-74.

Skipper, C. and Bell, L.C. (2008), "Leadership development and succession planning", Leadership and Management in Engineering, Vol. 8 No. 2, pp. 77-84.

Spreitzer, G. M. (1995a), "Psychological empowerment in the workplace: Dimensions, measurement and validation", Academy of Management Journal, Vol. 38 No. 5, pp. $1442-1465$.

Spreitzer, G. M. (1995b), “An empirical test of a comprehensive model of intrapersonal empowerment in the workplace", American Journal of Community Psychology, Vol. 23 No. 5, pp. 601-629.

Spreitzer, G. M. (1996), “Social structural characteristics of psychological empowerment”, Academy of Management Journal, Vol. 39 No. 2, pp. 483-504.

Spreitzer, G. (2008), “Taking Stock: A review of more than twenty years of research on empowerment at work", in Barling, J. \& Cooper, C. (Eds), The Handbook of Organizational Behaviour, Sage Publications, Thousand Oaks, California, pp. 54-72.

Spreitzer, G. M. \& Doneson, D. (2008), “Musings on the past and future of employee empowerment", in Cummings, T. (Ed), Handbook of Organization Development, SAGE Publications, Los Angeles, pp. 311-324.

Spreitzer, G. M. \& Quinn, R. E. (2001), A company of leaders: Five disciplines for unleashing the power in your workforce, San Francisco: Jossey-Bass. 
Spreitzer, G. M., Kizilos, M. A. \& Nason, S. W. (1997), “A dimensional analysis of the relationship between psychological empowerment and effectiveness, satisfaction, and strain”, Journal of Management, Vol. 23 No. 5, pp. 679-704.

Steiner, I. D. (1972), Group process and productivity, New York: Academic Press.

Stodill, R. M. \& Coons, A. E. (Eds) (1957), Leader behaviour: Its description and measurement, Research Monogram No. 88, Columbus, Ohio: Bureau of Business Research, The Ohio State University.

Strahan, R. \& Gerbesi, K. C. (1972), "Short, homogeneous versions of the Marlow-Crowne social desirability scale” Journal of Clinical Psychology, Vol. 28 No. 2, pp. 191-193.

Strang, K. S. (2005). "Examining effective and ineffective transformational project leadership", Team Performance Management, Vol. 11 No 3/4, pp. 68-103.

Tannenbaum, R. \& Schmidt, W. H. (1973), “How to choose a leadership pattern", Harvard Business Review, Vol. 51No. 3, pp. 162-180.

Tesluk, P., Mathieu, J. E., Zaccaro, D. J. \& Marks, M. (1997), “Task and aggregation issues in the analysis and assessment of team performance", in Brannick, M. T., Salas, E. \& Prince, C. (Eds), Team performance assessment and measurement: Theory, methods and applications, Mahwah, New Jersey: Lawrence Erlbaum.

Thompson, J. D. (1967), Organizations in action: Social science bases of administrative theory, New York: McGraw-Hill.

Toor, S. R. and Ofori, G. (2008a), “Tipping points that inspire leadership: an exploratory study of emergent project leaders", Engineering, Construction and Architectural Management, Vol. 15 No. 3, pp. 212-29. 
Toor, S. R. and G. Ofori (2008b). "Leadership for future construction industry: Agenda for authentic leadership." International Journal of Project Management Vol. 26 No. 6, pp. 620-630.

Toor, S. R. and Ofori, G. (2008c), "Taking leadership research into future: A review of empirical studies and new directions for research", Engineering Construction and Architectural Management, Vol. 15, No. 4, pp. 352-371.

Trist, E. L. \& Bamforth, K. W. (1951), "Some social and psychological consequences of the long-wall method of coal getting", Human Relations, Vol. 4 No. 3, pp. 3-38.

Tuuli, M. M. (2009), Empowerment and control dynamics in project teams: A multilevel examination of the antecedents and job performance consequences, $\mathrm{Ph} . \mathrm{D}$ Thesis, Department of Real Estate \& Construction, The University of Hong Kong, Hong Kong.

Tuuli, M. M. \& Rowlinson, S. (2007), "Empowering project teams: Toward an integrative conceptualization of empowerment”, in Ahmed, S. M., Azhar, S. \& Mohamed, S. (Eds), Proceedings of the 4th International Conference on Construction in the 21st Century (CITC IV). Gold Coast, Australia: CITV-IV, Miami, Florida, pp. 240-247.

Tuuli, M. M. \& Rowlinson, S. (2010), “What empowers individuals and teams in project settings? A critical incident analysis", Engineering, Construction and Architectural Management, Vol. 17 No. 1, pp. 9 - 20.

Van De Ven, A. H., Delbecq, A. L. \& Koenig, R. (1976), “Determinants of coordination modes within organizations", American Sociological Review, Vol. 41 No. 2, pp. 322338. 
Vinkenburg, C. J., Van Engen, M. L., Eagly, A. H. \& Johannesen-Schmidt, M. C. (2011), “An exploration of stereotypical beliefs about leadership styles: Is transformational leadership a route to women's promotion?", The Leadership Quarterly, Vol. 22 No. 1, pp. 10-21.

Walker, A. (2002), Project management in construction, Oxford, UK: Blackwell.

Wong, J., Wong, P. N. K. \& Heng, L. (2007), “An investigation of leadership styles and relationship cultures of Chinese and expatriate managers in multinational construction companies in Hong Kong”, Construction Management and Economics, Vol. 25 No. 1, pp. 95-106.

Yip, B. and Rowlinson, S. (2009), “Job burnout among construction engineers working within consulting and contracting organizations", Journal of Management in Engineering, Vol. 25 No. 3, pp. 122-130.

Yip, B., Rowlinson, S. and Siu O. L. (2008), "Coping strategies as moderators in the relationship between role overload and burnout", Construction Management and Economic, Vol. 26 No. 8, pp. 871-882. 